Piotr Karpiński

Papieski Wydział Teologiczny w Warszawie

\title{
BIBLIA W FILOZOFII DRAMATU KS. JÓZEFA TISCHNERA
}

\section{Myślenie religijne a kryzys idei oświeceniowej}

Myślenie religijne ${ }^{1}$ Tischnera pojawia się stosunkowo wcześnie w jego twórczości, bo już w tomie Myślenie według wartości odnajdujemy tekst o takim tytule $^{2}$. Za jego dojrzały wyraz uznaje się natomiast tom zatytułowany Spór o istnienie człowieka ${ }^{3}$. Myślenie religijne to swoisty pomost pomiędzy filozofią i teologią. Gdybyśmy wskazali trzy drogi myślenia, jakimi są filozofia, myślenie religijne i teologia, to myślenie religijne sytuuje się zdecydowanie bliżej filozofii niż teologii. Nie jest ono teologią, która odwołuje się do Objawienia, dogmatów, magisterium Kościoła, itp. Ale nie jest też filozofią w sensie poszukiwania czystych zasad. Myślenie religijne Tischnera ma swój początek w bardzo konkretnej sytuacji filozoficznej. Jak wiadomo, głównym przedmiotem zainteresowań Tischnera był człowiek. We wcześniejszych dziełach Tischner korzystał z aparatu pojęciowego filozofii współczesnej, zwłaszcza fenomenologii. Później jednak zorientował się, że filozofia znajduje się w pewnym impasie. Najogólniej mówiąc, poniosła porażkę idea oświeceniowa, stawiająca na poznanie rozumowe, a która nie była w stanie poradzić sobie z problemem zła, który doszedł do głosu

${ }^{1}$ Twórcą myślenia religijnego jest Abraham Joshua Heschel, którego myśl wyrasta źródłowo z tradycji biblijnej i teologii żydowskiej. Myślenie religijne kształtem przypomina elipsę, która obejmuje dwa pozostające w nieustannym napięciu bieguny: filozofię i religię. Zdaniem Heschela celem rozumu jest badanie relacji obiektywnych, zaś celem religii badanie relacji osobowych. Por. T. Gadacz, Historia filozofii XX wieku, tom 2, Kraków 2009, s. 615.

${ }^{2}$ J. Tischner, Myślenie religijne, w: tenże, Myślenie wedtug wartości, Kraków 2005 , s. 336-357.

${ }^{3}$ J. Tischner, Spór o istnienie człowieka, Kraków 2001. Powszechnie przyjmuje się, że jest to kontynuacja Filozofii dramatu, niejako jej drugi tom. Przy dokładniejszych badaniach pogląd ten jest trudny do utrzymania. Nie zgadza się z nim m.in. J. Filek. Por. Wokót myślenia religijnego, „Znak”, (2004), nr 5, s. 48. 
w sposób szczególny w XX wieku . Dlatego Tischner zwraca się ku religii, zwłaszcza ku Biblii, by znaleźć rozwiązanie problemu zła. Tak rodzi się myślenie religijne, które jednak wciąż jest antropologią filozoficzną.

Myślenie religijne jest więc pewnym przedłużeniem filozofii człowieka. Nie jest to teologia, nie chodzi w nim o badanie Boga i Jego Objawienia, lecz o badanie całej przestrzeni relacji między Bogiem a człowiekiem. Takie myślenie religijne ma charakter pozakonfesyjny - co prawda Tischner korzysta z zasobu określonych tradycji religijnych, głównie tradycji judeochrześcijańskiej, jednakże jego celem nie jest konfesyjność, lecz zrozumienie człowieka. Najkrócej można powiedzieć, że Tischner chciał zapytać, co religia ma do powiedzenia o człowieku. Jak zauważa Jan Andrzej Kłoczowski OP:

Na przykład fenomen łaski nie jest tylko pojęciem teologicznym. Łaska rozgrywa się także między ludźmi. W ten sposób pojęcie teologiczne podsuwa jakieś narzędzie, które odsłoni mi w przestrzeni międzyludzkiej coś, co przedtem było mało czytelne. Jest kilka takich czysto religijnych pojęć, które u Tischnera zostały zinterpretowane właśnie nieteologicznie [...]. W tym sensie jest to dalszy ciąg tego, co Rosenzweig nazwał »nowym myśleniem $\ll^{5}$.

Także według K. Tarnowskiego wiara jest dla Tischnera kluczem hermeneutycznym do zrozumienia człowieka ${ }^{6}$.

Można powiedzieć, że myślenie religijne Tischnera wpisuje się w podejście dialogiczne, które pokazało, że Biblia może rzucić interesujące światło na rozumienie człowieka. Ale dla Tischnera ważna była jeszcze jedna zasada, która szła w parze z założeniem dialogików - przekonanie o głębokiej jedności człowieka. Człowiek jest jednością, co znaczy tu, że jest wierzący i filozofujący zarazem. Tischner śmiało odwoływał się zarówno do tradycji filozoficznej, jak i do wiary biblijnej. Nie sposób jego zdaniem oddzielić w człowieku wiary od myślenia.

Ale i nie o samo zrozumienie człowieka tylko chodzi. Myślenie religijne nie jest poszukiwaniem czystych zasad i prawdy teoretycznej, abstrakcyjnej. Filozofia człowieka pojęta jako myślenie religijne ma niezwykle silny wymiar terapeutyczny. To nie tylko stworzenie własnej antropologii, lecz także pomoc człowiekowi i to w horyzoncie najbardziej zasadniczym - potępienia lub

${ }^{4} \mathrm{Z}$ doświadczenia horroru zła i nienawiści, cierpienia ofiar systemów totalitarnych $\mathrm{XX}$ wieku i wojen wyrosła filozofia dialogu. Wątek ten najbardziej widoczny jest u E. Lévinasa, który pisał: „Nasz wiek poznał dwie wojny światowe, totalitaryzm prawicy i lewicy, hitleryzm i stalinizm, Hiroszimę, Gułag, ludobójstwo w Auschwitz i Kambodży", (E. Lévinas, La souffrance inutile, „Giornale di Metafisica”, nr 1(1982), s. 20).

${ }^{5}$ Wokót myślenia religijnego, dz. cyt., s. 49.

${ }^{6}$ Tamże, s. 52. 
zbawienia. Jak pisze Tischner: „O jakości filozofii decyduje jakość bólu ludzkiego, który chce filozofia wyrażać i któremu chce zaradzać. Kto tego nie widzi, jest bliski zdrady"7.

Takie ujęcie łączy jednak myślenie religijne z filozofią grecką, która rozumiana była jako ćwiczenie duchowe. Skutkiem tego będzie też prymat doświadczenia $\mathrm{w}$ poznaniu.

W myśleniu religijnym zmienia się koncepcja prawdy. Prawda jest dla Tischnera nadal fundamentalną wartością, ale nie jest ona pojmowana przez niego w sposób klasyczny, jako adaequatio rei et intellectus. Prawda jest przede wszystkim prawdą osoby. Zasadniczym pytaniem będzie więc pytanie o wiarygodnego świadka, któremu można uwierzyć, a w efekcie zawierzyć. Nie jest to wyjście poza pole racjonalności. Żeby komuś zawierzyć trzeba mieć do tego podstawy. Jeśli kogoś uznajemy za autorytet godny zawierzenia, ten ktoś ofiaruje nam pewne dobro i wolność. A zatem to zawierzenie jest fundamentem myślenia religijnego. W Myśleniu religijnym Tischner używa ciekawego sformułowania: „ktoś mi myśli...”. Zawierzenie świadkom to nie jest zawierzenie pewnym tezom, lecz akt zawierzenia ich doświadczeniu. Prawdziwe myślenie rozpoczyna się od zawierzenia drugiemu, świadkowi i temu, co on mówi o naszych najbardziej podstawowych doświadczeniach.

Widzimy zatem, że filozofia człowieka Tischnera staje się myśleniem religijnym, a jej zasadniczym wyzwaniem będzie ocalenie człowieka w obliczu zagrażającego mu zła. W tak pojętej antropologii niezbywalną rolę odegra Biblia.

\section{Tischner czyta Biblię}

Biblia odgrywa zasadniczą, powiedzielibyśmy źródłową rolę w filozofii człowieka Tischnera, która przyjmie kształt filozofii dramatu. Co bardzo ważne, Biblia nie stanie się dla Tischnera jedynie zbiorem trafnych metafor, ilustrujących jego wywody, czy też zbiorem egzemplów do teorii przyjętej z góry. Filozofia dramatu istotowo wypływa z Biblii. Dlatego filozofia dramatu Tischnera o wiele bardziej wpisuje się w model myślenia biblijnego, aniżeli w model filozofii greckiej.

${ }^{7}$ J. Tischner, Czym jest filozofia, którq̨ uprawiam?, w: Myślenie wedtug..., dz. cyt., s. 9.

${ }^{8}$ Myślenie religijne, dz. cyt., s. 343. Platońskie w zasadzie sformułowanie „ktoś mi myśli” jest synonimem sformułowań: „ktoś mi sprzyja”, „ktoś mi oświetla drogę”, „ktoś powierza mi coś z siebie”. 


\subsection{Myślenie biblijne a filozofia grecka}

Możemy mówić o dwóch fundamentalnych paradygmatach filozofii, istotnie różniących się między sobą: greckim i biblijnym. Przy całej świadomości zastosowanych tu uproszczeń powiemy, że myślenie greckie to poszukiwanie istoty danej rzeczy. Pewne jest to, co stałe i niezmienne, a co wyrażone zostaje w pojęciach - stąd tak ważna rola definiowania i logiki. Zupełnie inaczej jest w Biblii. Jak pisze Tischner:

Biblia to inne problemy i inny sposób przedstawiania. W Biblii spotykamy się z prawdami przedstawionymi w formie obrazowej. Człowiek myśli obrazami, powiedziałbym nawet - obrazami dramatycznymi, i wspaniałymi, wielkimi symbolami. Należy pamiętać, że wchodząc w świat Biblii, sięgamy czasów daleko wcześniejszych, niż starożytna Grecja z jej ideą definiowania pojęć. Biblia jest tekstem religijnym, który nierzadko przyjmuje formę poetycką. Zadaniem poezji i religii nie jest odpowiadanie na wątpliwości przyrodoznawstwa, lecz dawanie ludziom nadziei ${ }^{9}$.

Biblia mówi o naturze człowieka i jego egzystencji, ale robi to inaczej, niż czyniła to filozofia grecka. Biblia nie formułuje definicji. „Mówi: być człowiekiem to znaczy uczestniczyć w takim samym dramacie, jaki stał się udziałem naszych prarodziców"10. Żeby uchwycić różnice w podejściu biblijnym i greckim, Tischner porównuje dwóch bohaterów: Ewę i Edypa ${ }^{11}$. Ich podobieństwo polega na tym, że oboje są winni. Ale widać też między nimi ogromną różnicę. Inna jest wina Ewy, a inna - wina Edypa. Edyp nie miał żadnego wyboru i z góry skazany był na klęskę, nie wiedział, kiedy popełnia czyn naganny. Inaczej Ewa. Uległa ona pokusie, ale kiedy prześledzimy pokusę biblijną widzimy, że wąż, symbolizujący zło, kusi słowem. Słowo kierowane do drugiego człowieka ma ogromną moc oddziaływania. Ale drugi na słowo musi odpowiedzieć. Tu nic się nie dzieje automatycznie. Ewa musi użyć swojej wolności, nie jest z góry skazana na zło. W Biblii słowo odgrywa ogromną rolę, ale od razu ewokuje ono wolność człowieka. Świat grecki to świat przyczynowo-skutkowy, niejako mechaniczny. Świat Biblii to świat dialogu i wolności.

Również zasadnicza różnica istnieje między Antygoną a Abrahamem. Jak pisze Tischner:

${ }^{9}$ Wokót Biblii. Z ks. Józefem Tischnerem rozmawia Ewelina Puczek, Kraków 2005, s. 7. Dalej jako WB.

${ }^{10} \mathrm{WB}, \mathrm{s} .10$.

${ }^{11}$ Tamże. 
Nasza cywilizacja podniosła motyw winy przenoszonej z rodziców na dzieci do rangi sztuki. Przykładem jest Edyp, którego zbrodnia ciążyła nad potomstwem. Nic nie mogło odwrócić tego losu; stąd tragedia Antygony. Ale kiedy przyjrzeć się historii Abrahama, sytuacja się odwraca. Błogosławieństwem ojca, jego nadzieją są synowie, błogosławieństwem, szczęściem matki są córki. W ten sposób świat nadziei buduje się od tej najmniejszej komórki społecznej, którą jest rodzina ${ }^{12}$.

Świat Biblii to zatem świat nadziei, w odróżnieniu od greckiego fatum.

Pomiędzy kulturą grecką a judeochrześcijańską istnieje zdaniem Tischnera konflikt. Krakowski filozof, analizując rozmowę Mojżesza z Bogiem na Górze Synaj, zauważa:

Grecja to przede wszystkim świat odbierany wzrokiem, wspaniała, piękna metafora światła. Fascynowali się nią Platon, Arystoteles. Nie da się ukryć, wrażenia wzrokowe są niesłychanie istotne w kontaktach międzyludzkich. Oto widzę człowieka, który idzie drogą, rozpoznaję jego sylwetkę, jego sposób chodzenia. Potem spoglądam na twarz, uśmiechniętą lub ponurą. Wreszcie koncentruję uwagę na oczach. Jak na mnie patrzą? Przyjaźnie czy wrogo? Jednakże w kontaktach z człowiekiem oczekujemy też zazwyczaj czegoś więcej. Jak się odezwie? Jak zareaguje na mój widok? I wtedy okazuje się, że nasze doświadczenie wzrokowe jest niewystarczające, że ma ograniczony zasięg. Chcąc zajrzeć do wnętrza człowieka, musimy posłużyć się słowem. Dopiero rozmowa z nim da nam odpowiedź na pytanie, co kryje w sobie, jakie ma wobec nas zamiary. Grecja, dla której wzrok był najważniejszym ze wszystkich zmysłów, była -w gruncie rzeczy - światem wielkich samotników. Owszem, filozofowie greccy nie uciekali od rozmów, bo potrzebowali siebie wzajemnie. Jeżeli jednak przyjrzeć się bliżej tym dysputom, to okaże się, że mamy do czynienia z uczonymi monologami. Brakuje tam wymiany myśli ${ }^{13}$.

Myślenie greckie jest więc monologiczne, Biblia zaś wprowadza nas w myślenie dialogiczne.

\subsection{Biblia jako wizja moralna}

Biblia jako księga uniwersalna wchodzi w kontakt z różnymi naukami. Można ją też traktować na różne sposoby. Opisami stworzenia świata i człowieka zajmują się na przykład nauki przyrodnicze. Istnieje debata metodologiczna pomiędzy teologami a naukowcami na temat prób uzgodnienia biblijnego kreacjonizmu z naukową wizją pochodzenia świata, jak Wielki Wybuch,

${ }^{12} \mathrm{WB}$, s. 70-71.

${ }^{13}$ WB, s. 58-59. 
czy ewolucjonizm. Takie naukowe, w sensie nauk przyrodniczych, podejście do Biblii Tischnera w ogóle nie interesuje, gdyż nic ono nie wnosi do filozofii człowieka. Biblia dla Tischnera to nie wizja przyrodnicza - ,jak powstał świat, to sprawa drugorzędna" 14 - lecz wielka wizja o charakterze moralnym. A problemem zasadniczym jest problem zła. Komentując Księgi Królewskie ze Starego Testamentu Tischner skonkluduje: „Grecy szukają Boga w przyrodzie, Żydzi w historii" ${ }^{15}$.

Tischner nie jest typowym egzegetą biblijnym. Nie interesują go szczegóły, czy pojedyncze słowa. Raczej czyta większe jednostki biblijne, szukając w nich obrazu generalnego. Podejście Tischnera do Biblii to bardziej poszukiwanie sensu całości, wielkiej wizji, aniżeli zawartości szczegółu. Stawia pytanie: o czym tak naprawdę mówi opis stworzenia świata? I pisze:

Żeby na nie odpowiedzieć, trzeba skoncentrować uwagę na całości opisu, a nie tylko na pierwszym zdaniu. Jeżeli zaakceptujemy taki sposób analizy tekstu, dojdziemy do przekonania, że w gruncie rzeczy chodzi tu o odpowiedź na pytanie: jak przezwyciężyć zło? Innymi słowy, biblijny opis stworzenia świata usiłuje odsłonić tajemnicę zła w różnych jego postaciach $^{16}$.

Tak więc w podejściu Tischnera do Biblii dominuje bardziej wrażliwość moralna, aniżeli naukowo-przyrodnicza. Zresztą różnica pomiędzy nimi ma charakter nieprzezwyciężalny:

Konflikt między wiarą a nauką to konflikt dwu moralności: moralności objawienia i moralności doświadczenia. Jedni mówią: nie wierzcie objawieniom, bo są fantazją. Drudzy: nie wierzcie doświadczeniom, bo one otępiają ducha. Czy konflikt ten daje się zażegnać? Myślę, że nie ${ }^{17}$.

Podstawowym błędem według Tischnera jest chęć przesadnego unaukowienia Biblii. Tymczasem trzeba ją czytać jak dzieło literackie. Biblia mówi o człowieku, nie o scenie, na której on żyje. Pod postacią wydarzeń historycznych Biblia objawia dramat, w jakim człowiek bierze udział. A jej największą troską jest ocalić człowieka od zagrażającego mu zła.

Biblia posługuje się innym językiem niż nauki przyrodnicze. Tischner stwierdza, że jest to szczególnego typu mowa - język prorocki. Jak powie, komentując grzech Dawida i posłannictwo proroka Natana:

\footnotetext{
${ }^{14}$ WB, s. 7.

${ }^{15} \mathrm{WB}, \mathrm{s} .165$.

${ }^{16} \mathrm{WB}, \mathrm{s} .6$.

${ }^{17} \mathrm{WB}, \mathrm{s} .8$.
} 
Jesteśmy świadkami krystalizowania się nie tylko pewnych idei, ale także szczególnego rodzaju mowy. Prorok nie mówi wprost, nie ocenia konkretnego zdarzenia, nie osądza. On tylko opowiada przypowieść. Dawid musi w tej przypowieści odszukać siebie i na podstawie opisanego przykładu samemu ocenić swój czyn ${ }^{18}$.

Jest to zdaniem Tischnera zupełnie osobny rodzaj komunikatu, tak charakterystyczny dla Biblii. Prorok jest moralistą, którego mowa ma pobudzać do refleksji. Nie narzuca on prawdy, ale pomaga w jej odkryciu, jest jakby akuszerem, który pomaga $\mathrm{w}$ jej narodzinach. Prorocka mowa Biblii podkreśla jej moralny charakter.

\subsection{Język symboliczny i potrzeba hermeneutyki}

Skoro Biblia jest dziełem literackim i wizją moralną, a nie księgą naukowo-przyrodniczą to należy dostrzec fakt, że język Biblii jest językiem symbolicznym. To także odróżnia myślenie greckie, dążące do ścisłego, poprawnego, jednoznacznego definiowania pojęć.

Mówiąc o symbolice biblijnej Tischner korzysta głównie z badań Paula Ricoeura, dla którego język religijny charakteryzuje się tym, że jest językiem symbolicznym właśnie. Adam, Ewa, wąż w raju, znamię Kaina, potop, miedziany wąż na pustyni, przejście przez Morze Czerwone - wszystkie te figury są symbolami. Czym jest symbol? Tischner powie: „Symbole mówią więcej, niż mówią. Bo mówią nie tylko o losach jednostek, ale mówią o losach pokoleń, mówią o losach każdego z nas"19.

W każdym symbolu Tischner wyróżnia trzy elementy ${ }^{20}$. Po pierwsze, symbol jest znakiem i to należącym do grupy znaków wieloznacznych. Oznacza to, że symbol znaczy więcej, niż znaczy. Po drugie, każdy tak pojęty znak ma dwa wektory - jeden wskazuje na sens dosłowny, np. plama na czole Kaina, drugi zaś na sens przenośny, np. wina Kaina. Zabieg symboliczny jest potrzebny, gdyż nie ma innego sposobu na bezpośrednie wyrażenie winy. Dlatego nadajemy słowu „plama” znaczenie symboliczne. I po trzecie, symbol mówi nie tylko o świecie, ale też mówi o nas. „Mówi o mnie i do mnie”- powie Tischner ${ }^{21}$. Symbole opisują świat, innych ludzi, ale tak naprawdę one opisują mnie. Dowiaduję się z nich o pewnych sprawach, które mają znaczenie dla mnie i mnie dotyczą. Jest to moment refleksyjny, moment zwrócenia się ku mnie, który występuje w każdym

${ }^{18} \mathrm{WB}, \mathrm{s} .145$.

${ }^{19} \mathrm{~J}$. Tischner, Hermeneutyka. Zagadnienie języka i interpretacji dziet językowych, w: Filozofia współczesna, red. J. Tischner, Kraków 1989, s. 164.

${ }^{20}$ Tamże.

${ }^{21}$ Tamże, s. 165. 
symbolu. Symbol porusza moją sprawę, a ponieważ jest ona tajemnicza, nie może jej poruszyć w sposób jednoznaczny.

To sprawia, że Biblia jest mową zawsze aktualną. Aktualność Biblii jest pochodną refleksyjnego charakteru symbolicznego języka biblijnego. Tischner, czytając Biblię, szukał często analogii do współczesnej sytuacji, co m.in. sprawiało, że był tak chętnie czytany i słuchany. Komentując narodziny Mojżesza powie:

Sprawy, które opisano w tej księdze, są zawsze aktualne. Gdyby się tak dobrze zastanowić, to właściwie trudno orzec, czy historia zdarzyła się nad Nilem, czy może tu, nad Wisłą... Odnosi się to także do pojęcia narodu wybranego, z którym się tu spotykamy. Przecież równie dobrze mogłoby chodzić o naród polski, a nie żydowski. Czy niewola, o której mowa, odnosić się ma wyłącznie do przeszłych czasów? Kto wie, może chodzi tu o niewolę, której poddane są różne narody żyjące współcześnie na kuli ziemskiej? [...] Rozmawiamy o zdarzeniach, które naprawdę kiedyś miały miejsce i mogą się powtórzyć zawsze i wszędzie. Innymi słowy - tamtą historię z powodzeniem można potraktować jako przyczynek do naszych własnych dziejów ${ }^{22}$.

Skoro język biblijny jest językiem symbolicznym, to w sposób naturalny wyłania się pytanie, jak go interpretować. Inaczej mówiąc, domaga się on jakiejś hermeneutyki. Pierwszym pytaniem, jakie stawia Tischner na tym polu, jest: czy tekst Biblii należy interpretować dosłownie, czy niedosłownie. Tischner powie: „Historie biblijne, w których zawierają się całe dramatyczne dzieje ludzkości, mają znaczenie symboli. Z tego wypływa wskazówka: „Nie szukajmy w Biblii dosłowności, bo jej tam nie znajdziemy"23. Jak zatem interpretować Biblię? Według Tischnera cenną wskazówką jest odpowiedź na pytanie, po co ten tekst został napisany? „Czy po to, żeby uczyć nas astronomii, geografii, historii? Czy może jednak po to, by kształtować nasze metafizyczne wyobrażenia o świecie?"24. Tak więc pierwszą wskazówką hermeneutyczną jest odpowiedź na pytanie o cel tekstu biblijnego i jego moralne przesłanie. Omawiając grzech Dawida z Batszebą Tischner powie:

Ale przy okazji tej zbrodni dokonuje się nowy krok ku objawieniu, jako że każde biblijne wydarzenie, dobre czy złe, ma swój określony, głęboko przemyślany cel. Całe zajście jest tak opisane, że czytelnik staje po stronie Uriasza oraz jego zniewolonej, pohańbionej żony. Chodzi zatem o zmia-

\footnotetext{
${ }^{22}$ WB, s. 45-46.

${ }^{23}$ WB, s. 22.

${ }^{24} \mathrm{WB}$, s. 114.
} 
nę sposobu myślenia. Poddani nie są własnością króla, nie on nimi rządzi, nie on decyduje o ich życiu i śmierci. Te ostateczne sprawy rozstrzyga jedynie Bóg ${ }^{25}$.

Czy na innym miejscu, komentując historię nierządnicy Rachab powie: „Biblia nie jest bajką dydaktyczną. Ale pokazując całą gamę zła, czyni to w określonym celu. Tym celem jest dążenie do dobra. Plon dobra wyrasta ze zła. Cała Boska dydaktyka polega na naprawianiu ludzi i ich uczynków ${ }^{26 "}$.

Tischner, korzystając z dorobku Ricoeura, podaje trzy zasady hermeneutyczne, dzięki którym mamy szanse dobrze odczytać język symboliczny ${ }^{27}$. Po pierwsze, należy sobie uświadomić, jakie mamy przedrozumienia. Nigdy nie przystępujemy do lektury tekstu z tzw. czystym umysłem, lecz w każdym rozumieniu jest zawarte jakieś przedrozumienie, które jest kształtowane zarówno przez osobistą historię i doświadczenie każdego, jak i przez historię społeczności, w jakiej ktoś żyje. Jak pisze Tischner:

Kiedy przystępujemy do rozumienia jakiegoś tekstu biblijnego, np. opowiadanie o Adamie i Ewie, każdy z nas przeżył już kawałek swojego życia, ma już jakieś doświadczenie świata [...]. Nie może się tej historii swojego osobistego życia pozbyć, czy chce, czy nie chce, tę historię wnosi w swoją próbę rozumienia ${ }^{28}$.

W ustalaniu naszego doświadczenia, z którym przystępujemy do rozumienia bardzo pomocna jest fenomenologia.

Drugi postulat hermeneutyczny Tischnera brzmi: nigdy nie rozumiemy całości przez jej części, ale odwrotnie, rozumiemy części przez całość. Jak pisze Tischner: „Rozumieć, to odkryć jakąś pełnię, w której zawiera się to, co mamy zrozumieć, to odnieść część do całości. Odnieść to, co niedoskonałe, do tego, co doskonałe ${ }^{29}$ ". Filozof podaje przykład rozumienia Adama u św. Pawła. Adam był typem Chrystusa, Chrystus jest nazywany nowym Adamem.

Kogo przez kogo tutaj rozumiemy? Nie rozumiemy tutaj Chrystusa przez Adama. Nasz bieg myśli nie jest taki, że od Adama idziemy do Chrystusa. Odwrotnie, przez Chrystusa dopiero możliwe jest zrozumienie dramatu Adama [...]. Chrystus jako drugi Adam sprawia, że postać pierwszego Adama jest dla nas zrozumiała ${ }^{30}$.

${ }^{25} \mathrm{WB}, \mathrm{s} .142$.

${ }^{26} \mathrm{WB}, \mathrm{s} .112$.

${ }^{27}$ J. Tischner, Hermeneutyka, dz. cyt., s. 166.

${ }^{28}$ Tamże.

${ }^{29}$ Tamże, s. 167.

${ }^{30}$ Tamże. 
Wreszcie trzecia zasada hermeneutyczna: rozumieć coś, to uchwycić coś jako coś, gdzie ważne jest słowo „jako”. Tu widać różnicę między hermeneutyką a metafizyką. Hermeneutyka buduje zdania wyrażające rozumienie i posługuje się w nich słowem ,jako", unikając słowa ,jest”, charakterystycznego dla metafizyki. Np. Chrystus jako drugi Adam. Słowo ,jako” umożliwia nieustanną zmianę kontekstu - można powiedzieć „Chrystus jako drugi Adam” (św. Paweł), ale też „Chrystus jako Logos” (św. Jan). To sprawia, że symbol jest niewyczerpalny, bogaty, nieustannie daje do myślenia.

Symbol mówi nie tylko o sprawach ludzkich. Nadaje się on także do mówienia o Bogu: „O istnieniu Boga nie można mówić językiem jednoznacznym, odwołującym się do potocznego doświadczenia, ponieważ Bóg jest inny; także Jego obecność jest inna niż obecność ludzi czy rzeczy"31". Mało tego, każdy znak jest sygnałem, że w sprawę wmieszał się Bóg. Mówi Tischner o plagach egipskich:

Bóg nie daje instrukcji, Bóg wysyła znaki [...]. Każdy znak jest dowodem, że w sprawę wmieszał się Bóg, i to musi skłaniać do refleksji, do zmiany postępowania. Jeżeli człowiek nie rozumie znaków dawanych przez Boga, to sytuację może zmienić tylko nieszczęście. Najbardziej charakterystyczną ilustracją tej myśli jest los Hioba ${ }^{32}$.

Widzimy zatem, że Tischnerowi obca jest nie tylko ontologia człowieka, ale także ontologia Boga - ontoteologia.

\section{Pierwszorzędny problem zla}

Dotąd śledziliśmy sposób traktowania i czytania Biblii przez ks. Tischnera. Jednakże na początku stwierdziliśmy, że filozofia dramatu istotowo wyrasta z myślenia biblijnego. Nie miejsce tu, by szczegółowo omawiać Tischnerowską filozofię dramatu. Wskażemy trzy główne składowe tej filozofii, których rodowód biblijny jest niekwestionowalny: napięcie między dobrem a złem, dramatyczna koncepcja człowieka oraz wizja Boga jako Absolutu dialogicznego.

Pierwszym z problemów biblijnych jest według Tischnera zagadnienie zła. Można nawet, ocierając się o pewną przesadę, powiedzieć, że Biblia powstała jako odpowiedź na zagrożenie człowieka przez zło. Przy czym nie chodzi o manichejską fascynację złem, lecz konieczność obrony człowieka, czyli zbawienia. Wszystkie historie biblijne utrzymane są w horyzoncie dobra i zła. Tischner powie: „Biblia to przede wszystkim problematyka zła i wszystkiego, co się z nim

\footnotetext{
${ }^{31}$ WB, s. 110.

${ }^{32} \mathrm{WB}$, s. 55-56.
} 
wiąże"33. Chodzi jednak o przezwyciężenie zła, a nie podkreślanie jego wagi. Już opis stworzenia świata i człowieka na pierwszych stronach Księgi Rodzaju wprowadza tę perspektywę: „biblijny opis stworzenia świata usiłuje odsłonić tajemnicę zła w różnych jego postaciach”. Robi to, wchodząc w polemikę z panującą wówczas kulturą sumero-akadyjską, która głosiła pogląd, że zło jest wieczne, a jego żywiołem jest materia. Według Biblii jest inaczej: po każdym dziele stworzenia Bóg stwierdza „i dobre było”. Myślenie biblijne otwiera więc nie tylko horyzont zła, ile napięcie między dobrem i złem. Świat jest dobry, choć człowiekowi zagraża zło. Jest to pierwsze w dziejach myślenie w kategorii nadziei, tak bliskie Tischnerowi.

W myśli Tischnera ujawnia się bardzo ważne założenie co do samej istoty człowieka. Jego zdaniem człowiek jest ,jedyną istotą na świecie, o której możemy bez zastrzeżeń powiedzieć, że może być dobra" ${ }^{34}$. Przy czym dobro nie jest tylko i wyłącznie domeną dobrej woli. Dobro dane jest nam w wydarzeniu spotkania. Możemy powiedzieć, że dobro ma dialogiczny charakter. Ono się objawia: „[...] tajemnica dobra na tym polega, że człowiek, który ogląda dobro drugiego człowieka, sam staje się dobry"35. Atrakcyjność dobra jest jego ważną cechą dobro pociąga. Dobro samo się rozprzestrzenia - Tischner pozostaje tu w zgodzie z klasyczną zasadą filozofii scholastycznej bonum diffusivum sui: „Na tym właśnie rzecz polega, że dobro rozprzestrzenia się samo. Ono nie potrzebuje przykazań, nakazów, nie potrzebuje napędzania, żeby przechodziło z człowieka do człowieka [...]. Dobro ma bowiem to do siebie, że wystarczy je raz zobaczyć, ażeby samemu chcieć być dobrym ${ }^{36 "}$.

Ukazując tę prawdę o człowieku, Tischner sięgnął do rozważań św. Augustyna. Biskup Hippony postawił pytanie, czy człowiek może być twórcą. Odpowiedź może być pozytywna tylko przy założeniu, że tworzenie pojmiemy jako wytwarzanie, czy przetwarzanie, a nie stwarzanie z niczego (creatio ex nihilo), które jest właściwe tylko Bogu. Niemniej, zauważa św. Augustyn, jest taka dziedzina życia, gdzie ludzka twórczość stawia nas w bardzo bliskim sąsiedztwie Pana Boga: ,jest to dziedzina dobra"37. Tischner, w ślad za św. Augustynem, zauważa, że w dziedzinie dobra człowiek jest prawdziwym twórcą. W jaki sposób? „Człowiek może tworzyć dobro - powiada Tischner - w ten sposób, że odpowiada na

${ }^{33}$ WB, s. 16.

${ }^{34}$ J. Tischner, Pokój ludziom dobrej woli, w: Wiara ze stuchania. Kazania starosądeckie 1980-1992, oprac. W. Bonowicz, Kraków 2009, s. 112.

35 Tamże, s. 114.

${ }^{36}$ Tamże, s. 115.

${ }^{37}$ NA-223. Tak oznaczone są nagrania konferencji, wykładów i kazań ks. J. Tischnera, zgromadzone w Archiwum Instytutu Myśli Józefa Tischnera w Krakowie. Pełna bibliografia nagrań: P. Karpiński, Zrozumieć człowieka. Antropologia kazań Ks. Józefa Tischnera, Sandomierz 2012, s. 275-279. 
zło dobrem"38. Gdybyśmy odwołali się do porównań, jakie podaje św. Augustyn, to odkrylibyśmy pewien paradoks: tak, jak np. rzeźbiarz potrzebuje marmuru, który stanie się tworzywem dla jego dzieła, tak człowiek w pewnym sensie potrzebuje zła, żeby móc urzeczywistniać dobro. Zło jawi się jako tworzywo dla dobrego działania człowieka, a przecież z drugiej strony takim tworzywem być nie może. Ten paradoks zawarty jest w słowach św. Pawła: „zło dobrem zwyciężaj" (por. Rz 12,21). Jak go wyjaśnić?

Zdaniem Tischnera nie ma bezpośredniego przejścia od zła do dobra, od kłamstwa do prawdy, to znaczy: „nie jest tak, żeby ze świata kłamstwa można było drogą jakiegoś logicznego wnioskowania przejść do świata prawdy. Aby przejść do świata prawdy potrzeba człowieka. Ten człowiek musi podjąć wewnętrzną decyzję, że będzie inaczej, i bierze się ona tylko z jego wewnętrznej wolności i9". Widzimy zatem wyraźnie, że zło nie jest tworzywem dla dobra, nie jest także jego przyczyną, czy racją dostateczną. Dobro ma personalistyczny charakter i wypływa z wolności człowieka. Pomiędzy złem a dobrem nie ma żadnej logicznej ciągłości - stąd jako brakujące ogniwo potrzebny jest człowiek, który w swojej wolności podejmie decyzję przejścia od zła do dobra. Przykładem tak zrealizowanej zasady był dla Tischnera ks. Jerzy Popiełuszko.

$\mathrm{Na}$ czym polega istota zła? Dzięki rozważaniom św. Augustyna wiemy, że zło nie ma istnienia samoistnego. Nie jest ono tworzywem dla dobra, raczej samo istnieje na podłożu jakiegoś dobra. Ale z drugiej strony zło w jakiś sposób jest obecne, zagraża człowiekowi. Tischner ukazuje sposób istnienia zła, posługując się metaforą cienia albo zjawy. Zjawa ma ,istnienie pozoru"40. Jawi się człowiekowi, ażeby go przestraszyć, łudzić, wprowadzać w iluzję.

Tajemnicy zła obecnego w codziennym życiu człowieka Tischner poświęca wiele miejsca w swoich rozważaniach ${ }^{41}$. Krakowski filozof do poznania istoty zła dochodzi przez przyglądanie się różnym jego przejawom w życiu człowieka. Mamy tutaj zastosowaną metodę fenomenologicznego opisu zjawiska w celu poszukania jego istoty. Jak pisze:

\footnotetext{
${ }^{38}$ Tamże.

39 Tamże.

40 Tamże, s. 31 .
}

${ }^{41}$ Filozofia zła J. Tischnera doczekała się bogatej literatury. Por. T. Gadacz, Problem zła w filozofii Józefa Tischnera, „Horyzonty Wychowania” 2005, nr 4, s. 21-40. Z. Dymarski, Dwugłos o złu. Ze studiów nad myślą Józefa Tischnera i Leszka Kołakowskiego, Gdańsk 2009, s. 71-122. A. Bobko, Myślenie wobec zła. Polityczny i religijny wymiar myślenia w filozofii Kanta i Tischnera, Kraków-Rzeszów 2007, s. 131-249. A. Bobko, Doświadczenie zła jako źródło myślenia religijnego, w: Między potępieniem a zbawieniem. Myślenie religijne ks. Józefa Tischnera, wstęp F. Macharski, red. J. Jagiełł, W. Zuziak, Kraków 2004, s. 149-159. 
Biblia to przede wszystkim problematyka zła i wszystkiego, co się z nim wiąże. Objawia się ono rozmaicie. W przypadku Adama i Ewy złem było kłamstwo, które uosabiał wąż. Natomiast zło Adama [...] to bunt wyrażony za pomocą słów. W historii Kaina i Abla mamy do czynienia z czymś innym. Tutaj zło zamienia się w czyn. Dochodzi do morderstwa, przelana zostaje $\mathrm{krew}^{42}$.

Do tych form zła należałoby jeszcze dołożyć zdradę, niewierność, szemranie, zawiść, odwet itp. Co łączy te wszystkie formy zła? Dokonują się one praktycznie między ludźmi. Jeszcze raz widzimy, jak w Biblii perspektywa etyczna dominuje nad ontologiczną. Biblia dociera do tego, co typowo ludzkie, niesprowadzalne do żadnych innych bytów, i chce ludzkie zło zinterpretować ,po ludzku”"43. Przejawem zła „ludzkiego” jest słowo - ono odgrywa w Biblii zasadniczą rolę. Tischner twierdzi, że „również za sprawą słowa narodziło się zło [...], pojawiło się ono nie w samych ludziach, ale gdzieś między nimi. Adam był dobrym człowiekiem, Ewa też; zła musimy szukać na styku dwojga ludzi, którzy stoją wobec jakiegoś wyboru"4",

Zdaniem Tischnera Biblia rozgranicza zło wewnętrzne od zła zewnętrznego. To ostatnie przychodzi do nas z zewnątrz i jest możliwe ze względu na cielesność człowieka. Przejawia się ono „w chorobach, niezgodzie, pokusach..."45 i nie jest największym zagrożeniem człowieka. Jego granicą jest duchowa strona człowieka, na co wskazują słowa Jezusa: „Czego się boicie? Duszy zabić nie mogą” (por. Mt 10,28). O wiele groźniejsze jest zło wewnętrzne, które poczyna się w duszy człowieka, „gdzieś tam w czeluściach ludzkiego ducha, w którym lęgną się na wpół świadome intencje, zamiary, pragnienia i pożądania" ${ }^{46}$. Jak się ono przejawia? Tischner odpowiada: „zaślepieniem, obłąkanym pragnieniem niszczenia dobra, a właściwy sobie bezmiar osiąga w nienawiści, która jest niczym innym, jak niezdolnością człowieka do wybaczania" ${ }^{47}$. Oprócz tych dwóch wymiarów zła, Tischner mówi jeszcze o złu społecznym, które nie tylko dotyka pojedynczego człowieka, ale jest wszczepione w cały organizm społeczny. Symbolem zła społecznego staną się dla Tischnera Oświęcim i Kołyma. Także i tutaj obowiązuje zasada św. Pawła: „nikomu złem za zło nie odpłacajcie”.

W jaki sposób zło działa? Pierwszym przejawem działania zła jest to, że zło wybiera. Upatruje dla siebie najsłabszego miejsca w człowieku, a następnie wchodzi w nie, by pasożytować na dobrej woli człowieka. Przykładem takiego

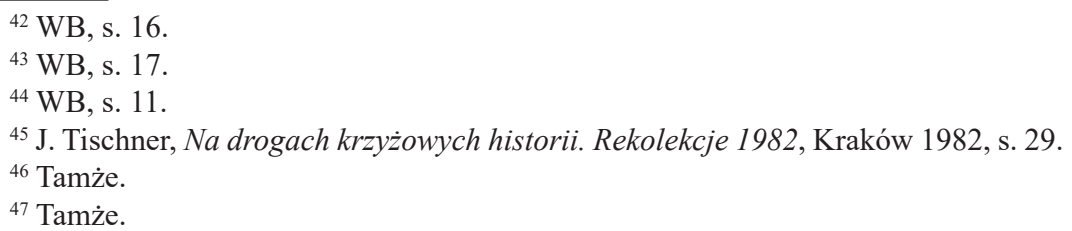


działania zła jest św. Piotr, który wszedł na dziedziniec arcykapłana z dobrą intencją, która jednak obróciła się przeciwko niemu. „Logika zła jest prosta: posłużyć się człowiekiem tam, gdzie ono samo jest bezsilne"48.

Bardzo ważnym sposobem działania zła jest kuszenie, uwodzenie, wprowadzenie człowieka w iluzję. Tischner komentując historię Szczepana z Dziejów Apostolskich zastanawia się, jak to możliwe jest, że ginie człowiek sprawiedliwy. Jego zdaniem w historii Szczepana jeden moment jest szczególnie ważny. Oskarżyciele byli absolutnie przekonani, że mają rację i że kamienując, postępują zgodnie z prawem: „Cały dramat świętego Szczepana na tym polega, że oni byli przekonani, iż postępują zgodnie z prawem, że kamienują legalnie. Ukamienowali go, zapominając o tym, że w dziesięciu Bożych przykazaniach jest przykazanie: nie zabijaj. Zabili w przekonaniu, że postępują w imię prawa ${ }^{49}$ ". Zdaniem Tischnera historia ta dobrze pokazuje, na czym polega iluzja - mechanizm działania zła. To taki rodzaj zakłamania, które skutkuje niszczeniem dobra. Inne imię iluzji to głupota. Tischner mówi wyraźnie o „grzechu głupoty”. Często sięga po księgi mądrościowe Starego Testamentu, które, jego zdaniem, ukazują ten podstawowy grzech ludzkości. Również ewangeliczna opowieść o synu marnotrawnym ukazuje dzieje głupoty ludzkiej. Filozof zastanawia się: cóż takiego legło u źródeł synowskiego odejścia? Czy może była w synu marnotrawnym jakaś zła wola? „Nie! U źródeł była jakaś iluzja, jakiś błąd, raczej głupota młodzieńcza, niż jego zła wola"50.

Mówiąc o złu, można mówić także o pewnym błądzeniu człowieka. Człowiek ma dobrą wolę, ale jest ona na tyle osłabiona, że nie widzi wyraźnie dobra. W Piśmie Świętym można znaleźć wiele tekstów mówiących o błądzeniu człowieka, ale zdaniem Tischnera, zwłaszcza werset z proroctwa Izajasza pokazuje nam tajemnicę błądzenia: „Ten lud czci mnie wargami, ale sercem daleko jest ode Mnie" (Iz 29,13). Tischner pokazuje trzy sytuacje serca błądzącego. Pierwsza polega na tym, że „serce błądzi, ponieważ zamieszkał w nim lęk, strach" ${ }^{51}$. Przykładem jest Nikodem, który choć szukał prawdy, to jednak przyszedł do Jezusa w ukryciu, potajemnie, „krył się przed oczyma faryzeuszów, żeby o nim źle nie myślano, żeby się nie narazić na niebezpieczeństwo" 52 . Innym przejawem błądzenia jest serce uwiedzione zgryzotą: ,zgryzota wczepia się w ludzkie serce jak jakiś zły robak i gryzie to serce [...]. Kto ma zgryzotę w sercu, ten wszystko odczytuje jako powód do smutku, do nowej zgryzoty ${ }^{53}$ ". Tischner podaje tu

\footnotetext{
48 Tamże, s. 31.

${ }^{49}$ J. Tischner, Szczepan - ofiara ludzkich iluzji, w: Wiara ze stuchania, dz. cyt., s. 227.

${ }^{50} \mathrm{NA}-123$.

${ }^{51}$ J. Tischner, Bładzace serca, w: Wiara ze stuchania, dz. cyt., s. 221.

52 Tamże.

${ }^{53}$ Tamże.
} 
przykład Marty z domu Łazarza: „serce, które pełne zgryzoty krzątało się wokół takiej czy innej sprawy, że nie zauważyło gościa w swoim domu"54. I wreszcie trzecia sytuacja, najgorsza, to serce złe: „takie, które wszystko na zło thumaczy i na zło przekształca"55. Przykładem są faryzeusze, którzy tak skomentowali cud wypędzenia złego ducha, jakiego dokonał Jezus: „mocą złego ducha wyrzuca czarty" (por. Mk 3,22). Złe serce w każdym dobrym uczynku podejrzewa coś złego.

Skoro zło to iluzja, błąd, zakłamanie, to jasnym się staje, że droga pokonywania zła będzie prowadziła przez prawdę. Ale, jak stwierdziliśmy, prawda u Tischnera nie jest wartością logiczną zdania, lecz ma charakter personalistyczny: „Najpierw i przede wszystkim prawda jest człowiekiem. Człowiek jest pierwszą i podstawową prawdą na tym świecie, a zarazem pierwszym i podstawowym kłamstwem" 56 . Tischner powołuje się na słowa Jezusa, który mówi sam o sobie: „Ja jestem Prawdą” (por. J 14,6), ale także o innych, np. o Natanaelu: „Oto Izraelita, w którym nie ma zdrady” (por. J 1,47), czy o św. Piotrze: ,jesteś opoką" (por. Mt 16,18). To człowiek, do którego można mieć zaufanie, jest prawdą. Poznać prawdę to zawierzyć komuś godnemu zaufania. Człowiek przybliża się do prawdy, kiedy z drugim tworzy związek zawierzenia, bo „początkiem zła jest obumieranie relacji zawierzeń" 57 .

$\mathrm{Na}$ koniec zapytajmy o ewangeliczną drogę prowadzącą do zwycięstwa w dramacie dobra i zła. Tischner przywołuje kilka zasad biblijnych, jak choćby wspomniane słowa św. Pawła: „zło dobrem zwyciężaj”. Odpowiadając dobrem na zło, człowiek zbliża się do Boga i poszerza horyzont swojej wolności. Staje się prawdziwym twórcą i może dokonywać cudów, bo prawdziwy cud „polega na tym, że ze zła nie powstaje zło, ale powstaje dobro"58. Chrześcijanin w walce ze złem powinien przyjąć strategię dwóch kroków: po pierwsze rozumieć zło i jego mechanizmy, czyli być świadomym dramatu, w jakim się bierze udział; po drugie zaś zło pokonywać siłą dobra, a to z kolei wymaga heroizmu. Tischner formułuje swoją zasadę: „Nie bądźcie przyjaciółmi zła, ale nie bądźcie także jego dosłownymi wrogami" ‘9. Czy nie kryje się tu zakamuflowany pacyfizm, irenizm, paktowanie ze złem? Zasada Tischnera staje się w pełni zrozumiała w kontekście

54 Tamże.

55 Tamże, s. 222.

56 Tenże, Czas nawiedzenia, w: tenże, Miłość niemiłowana, Kraków 1993, s. 88. Ten wątek myśli Tischnera omawia R. Buttiglione, stawiając jednakże pytanie, czy odrzucenie obiektywności prawdy u Tischnera nie posunęło się zbyt daleko. Por. R. Buttiglione, Osobowy charakter prawdy, przeł. M. Przychodzeń, w: O autorytecie. W poszukiwaniu punktu odniesienia, red. J. Jagiełł, Kraków 2008, s. 169-186.

${ }^{57}$ J. Tischner, Czas nawiedzenia, w: Miłość niemiłowana, dz. cyt., s. 89.

${ }^{58} \mathrm{NA}-154$.

${ }^{59}$ J. Tischner, Na drogach krzyżowych historii, dz. cyt., s. 32. 
słów św. Pawła: „Bóg jest mścicielem wszystkich tych (złych - P. K.) rzeczy” (por. 1 Tes 4,6). Filozof wskazuje na Eucharystię, która jest „siewem rzuconym w świat przez próg śmierci" ${ }^{60}$. Ona uczy nas właściwej strategii wobec zła: czynić dobro (metafora siania pszenicy), nawet w obliczu zła. Zło samo w sobie niesie własną zagładę i nigdy ostatecznie nie zwycięża.

Człowiek według Tischnera jest jedyną istotą na ziemi, która ma wolną wolę i może stawać się dobra. Ale filozof dostrzega także, że człowiek jest jedyną istotą na ziemi, która na zło może odpowiedzieć dobrem. U Tischnera mamy więc nie tylko optymistyczną wizję człowieka i jego dramatu, lecz także przezwyciężenie manichejskiej fascynacji złem i pogańskiego fatum, wiszącego nad człowiekiem, które oznacza nieuchronność zła. Obydwa poglądy nie mają nic wspólnego z myśleniem biblijnym. Człowiek bierze udział w dramacie, ale dzięki perspektywie agatologicznej widzimy, że dramat jest czymś innym niż tragedia. Ta ostatnia oznacza całkowite i beznadziejne uwikłanie losu człowieka w zło, z którego nigdy nie można się wyplątać. Wyrażała to pogańska koncepcja fatum, w której zło jest nieprzezwyciężalne. Tymczasem dramat człowieka toczy się w horyzoncie dobra i zła, a człowiek może stawać się dobry, może w swojej wolności wybierać dobro. Dramat człowieka jest więc dramatem nadziei.

\section{Dramat czlowieka}

Najbardziej dojrzała odpowiedź, jaką daje Tischner na pytanie o człowieka, jest następująca: „Człowiek jest istotą dramatyczną. Człowiek bierze udział w jakimś dramacie" ${ }^{\text {" }}$. Koncepcja ta zostaje rozwinięta i zaprezentowana w dziele Filozofia dramatu, gdzie Tischner pisze: „Być istotą dramatyczną znaczy: przeżywać dany czas, mając wokół siebie innych ludzi i ziemię jako scenę pod stopami. Człowiek nie byłby egzystencją dramatyczną, gdyby nie te trzy czynniki: otwarcie na innego człowieka, otwarcie na scenę dramatu i na przepływający czas" ${ }^{62}$. Człowiek jest więc dla Tischnera istotą dramatyczną, a jest to wizja mająca źródło biblijne. Na jednej z konferencji paryskich wyznał:

Dla mnie osobiście od szeregu lat nicią przewodnią w refleksji nad człowiekiem są słynne słowa świętego Pawła: »dobra, którego chcę nie czynię, a czynię zło, którego nie chcę«. Święty Paweł zaczyna te słowa: »nieszczęsny ja człowiek«. I ile razy mam na tyle czasu i skupienia, i siły, żeby $\mathrm{w}$ rozmowie $\mathrm{z}$ drugim człowiekiem, zwłaszcza w dramatycznych momen-

${ }^{60}$ Tamże.

${ }^{61} \mathrm{~J}$. Tischner, Zarys filozofii człowieka dla duszpasterzy i artystów, w: Myślenie w żywiole piękna, Kraków 2004, s. 139.

${ }^{62}$ J. Tischner, Filozofia dramatu, Kraków 2006, s. 5. 
tach, uprzytomnić sobie słowa świętego Pawła, tyle razy mogę powiedzieć, że istnieje jakieś porozumienie pomiędzy mną a tym, z kim rozmawiam. Bo w sumie człowiek jest nieszczęsny. I nieszczęsny z powodu tego dramatu niesamowitego, że dobra, którego chce nie czyni, a czyni zło, którego nie chce i że w tym czynieniu i nie czynieniu człowiek potrzebuje i rady, i pomocy, a przede wszystkim potrzebuje zbawienia ${ }^{63}$.

Człowiek jest tutaj istotą dramatyczną, którego dramat rozgrywa się w horyzoncie dobra i zła. Ale jednocześnie potrzebuje on zbawienia, stąd bardzo ważny jest dramat religijny: „Człowiek bierze udział w dramacie religijnym”64.

Przyjrzyjmy się elementom dramatu, w którym bierze udział człowiek. Struktura dramatu Tischnerowskiego jest potrójna: czas, scena i spotkanie.

Pierwszym elementem dramatu jest czas. Człowiek jest istotą czasową, historyczną. Jednakże czas, o jaki chodzi w dramacie, to nie czas matematycznego przyrodoznawstwa. Tischner nazywa go „czasem dramatycznym” i nie tyle otacza on człowieka z zewnątrz, ile przepływa przez samo jego wnętrze, a przepływając, kształtuje je. Tischner posługuje się biblijnym terminem kairos. Chodzi tutaj o „właściwy czas”, o moment, w którym wydarza się coś zasadniczego, co będzie miało dla człowieka dalsze skutki. W Biblii wszystko, co ważne ma swój czas: ,„)Gdy nastała pełnia czasu - mówi Jan Ewangelista - słowo stało się ciałem «, Jerozolima nie poznała czasu nawiedzenia swego, Jezus mówi do swoich uczniów: »mój czas jeszcze nie nadszedł«, przykłady można by oczywiście mnożyć" ${ }^{65}$. Tak więc termin kairos staje się odpowiednikiem czasu dramatycznego. Niekiedy także Tischner posłuży się ewangelicznym określeniem „,czas nawiedzenia", co oznacza, że w czasie dramatycznym dochodzi do jakiegoś spotkania, „,zas, w którym człowiek nawiedza drugiego człowieka i albo między ludźmi zawiązują się jakieś głębsze więzy przyjaźni, wierności, albo ludzie się rozchodzą" ${ }^{\prime 6}$. To jest również czas nawiedzenia przez Boga. W ten sposób czas dramatyczny otwiera człowieka na dramat religijny i wyłania się odwieczne pytanie człowieka: „czy ten czas nawiedzenia, kairos, jest czasem łaski, czy czasem jakiegoś fatum?" ${ }^{67}$. Czas dramatyczny różni się od tego z nauk przyrodniczych tym, że ma swoją wewnętrzną logikę. Nie można go zawrócić, jest ciągły i nieodwracalny. To, co się wydarzyło, nie może być odwołane. Czas kształtuje człowieka, zmienia go, ale może go także zniszczyć.

Drugim elementem dramatu jest przestrzeń. W swojej filozofii świat otaczający człowieka Tischner będzie nazywał „sceną dramatu”. Tischner inspirując
${ }^{63} \mathrm{NA}-230$.
${ }^{64} \mathrm{NA}-301$.
65 NA-64.
${ }^{66}$ Tamże.
${ }^{67}$ Tamże. 
się Biblią, rozwija w swoim dziele różne obrazy przestrzeni, czyli sceny: dom, warsztat pracy, świątynia, cmentarz. W miejscach tych dzieją się różne dramaty człowieka. Dom przesądza o tym, czy ktoś jest zadomowiony, czy też bezdomny. Jest on „wcieleniem ludzkiej miłości” ${ }^{68}$. Dom jest także miejscem wzajemności ${ }^{69}$, jest miejscem, w którym spotykają się ludzie. Istotę domu oddaje słowo „mieć”: „Mówimy »mój dom«. Ale jeszcze głębiej mówimy »moja matka«, »mój ojciec«, »moje dzieci«, »moja rodzina« $[\ldots]]^{\prime} 70$. Warsztat pracy ukazuje dramat człowieka pracy. Praca ma dwie cechy: po pierwsze, wyrazem jej wartości jest fakt, że ten, kto ją wykonuje, jest osobą, praca ma więc charakter personalistyczny; po drugie, praca łączy ludzi ze sobą, ma siłę budowania wspólnoty, praca ma charakter dialogiczny. Dramat pracy regulują słowa ewangeliczne: „Niechaj mowa wasza będzie tak - tak, nie - nie, a co nadto, od złego jest"(Mt 5,37), a polega on na tym, że może się w nią wkraść kłamstwo: wyzysk, nierzetelność pracy, wadliwy produkt pracy, itp. Najpiękniejszym, zdaniem Tischnera, elementem krajobrazu jest świątynia. Jest ona miejscem świętym, sceną, na której dochodzi do spotkania z Bogiem. Świątynia jest także miejscem ofiary, ciszy, przez to świątynia jest miejscem szczególnego wglądu człowieka w samego siebie. W krajobrazie otaczającym człowieka jest jeszcze cmentarz, którego człowiek doświadcza jako miejsca rozstania, pożegnania, wspomnień. Ale chrześcijaństwo zmienia sens cmentarza w taki sposób, że nie jest on już miejscem pożegnania, ale spotkania: „Idziemy na cmentarz nie po to, ażeby żegnać, ale idziemy po to, ażeby spotkać" "11. Spoczywający na nich przodkowie mają nam do przekazania swoje dziedzictwo. Także i na cmentarzu otwiera się horyzont możliwego dramatu - dramatu braku wierności.

Już to spojrzenie na krajobraz otaczający człowieka pozwala nam uchwycić dramatyczność człowieka. Scena, krajobraz, świat rzeczy staje się podłożem, na którym rozgrywają się istotne dramaty człowieka. W ten sposób dochodzimy do trzeciego elementu w strukturze dramatu, jakim jest spotkanie z drugim człowiekiem.

Czym jest spotkanie człowieka z człowiekiem? Tischner powie: „Spotkanie to niezwykłe przeżycie, dzięki któremu człowiek może do drugiego człowieka powiedzieć «mój«. Ty jesteś mój, ja jestem twój”’². Tym, co ustanawia relację z drugim człowiekiem, jest słowo. Nic więc dziwnego, że kiedy Tischner opisuje wydarzenie spotkania, chętnie sięga po werset biblijny: „Na początku było

${ }^{68} \mathrm{NA}-133$.

${ }^{69} \mathrm{~J}$. Tischner, O Bożym Narodzeniu, w: Książeczka pielgrzyma, Kalwaria Zebrzydowska 2002, s. 76.

${ }^{70} \mathrm{NA}-133$.

${ }^{71}$ J. Tischner, Rozmowa ze zmartymi, w: Wiara ze stuchania, dz. cyt., s. 9.

72 NA-237. 
Słowo, a Słowo było u Boga, i Bogiem było Słowo" (J 1,1). Słowo jest pierwsze, bo dzięki niemu może dojść do spotkania, ono oznacza otwartość człowieka, dzięki której spotkanie jest możliwe. W wyniku wymiany słowa pomiędzy człowiekiem a człowiekiem ustanawia się więź wierności: „Słowo dane drugiemu człowiekowi rodzi w człowieku wierność" ${ }^{\prime 73}$.W wyniku spotkania pomiędzy człowiekiem a człowiekiem ustanawia się wzajemność. Cóż ona oznacza? „Wzajemność pojawia się tam, gdzie istnieje wiele osób i między tymi osobami zachodzi wymiana jakichś darów"74. Jednakże, jak zauważa Tischner, człowiek nie miałby nic do zaoferowania drugiemu, gdyby nie wcześniejsze wydarzenie spotkania. We wzajemności wymienia się te dary, których by się nie posiadało, gdyby się żyło na świecie samemu.

Do spotkania na scenie dramatu nie dochodzi tylko pomiędzy człowiekiem a człowiekiem. Tym, kto kieruje słowo do człowieka jest w pierwszej kolejności Bóg. Bóg sam jest Słowem, które przyjmuje ciało i mieszka pomiędzy ludźmi: „Słowo stało się ciałem i mieszkało między nami” (por. J 1,14). Widać to w scenie narodzenia Jezusa: „Słowo pojawiło się między ludźmi. Nie w Maryi samej i nie w samym Józefie, i nie w pasterzu, ale między nami. Słowo staje się ciałem i pojawia się między ludźmi"75. Możemy powiedzieć, że nie ma dramatu ludzkiego, nie ma wydarzenia spotkania bez Boga: „Bóg pojawia się w tej przestrzeni, która istnieje między człowiekiem a człowiekiem, między mną a tobą, między nami. Nie jest w tobie, nie jest we mnie. Jest między nami" ${ }^{\prime 76}$. Bóg zatem jest uczestnikiem naszego dramatu. Czy można pomyśleć sobie dramat człowieka bez Boga? Czy dramat człowieka z Bogiem nie jest najważniejszym dramatem człowieka? Tischner mówi: „Kiedy człowiek jest sam, kiedy człowiek ucieka od drugiego człowieka, wtedy nie ma wzajemności - i wtedy nie ma Boga. Kiedy człowiek doświadcza wzajemności, wtedy Bóg znajduje się obok niego, wtedy Bóg znajduje się między ludźmi" 77 . W tym kontekście wspaniale brzmią słowa Tischnera, że „człowiek niesie w sobie ślad Boga"78.

Model spotkania został zdaniem Tischnera ukazany w Księdze Wyjścia, w opisie przebywania Mojżesza na Synaju. Początkowo towarzyszy temu niezwykła, kosmiczna sceneria, w której groźne żywioły symbolizują obecność Boga (por. Wj 19-20). Bardzo szybko jednak całe to zjawisko traci na wyrazistości, ustępując miejsca słowu. Tylko słowo bowiem jest w stanie wprowadzić nas do wnętrza. Pan Bóg ogranicza Mojżeszowi widzenie wzrokowe, by całą jego uwa-

${ }^{73}$ J. Tischner, Stowo stało się ciałem, w: Wiara ze stuchania, dz. cyt., s. 151.

${ }^{74}$ Tenże, Wzajemność, w: Wiara ze stuchania, dz. cyt., s. 24.

75 Tenże, Zamieszkało miedzy nami, w: Wiara ze stuchania, dz. cyt., s. 77.

${ }^{76}$ Tamże.

77 Tenże, Wzajemność, w: Wiara ze stuchania, dz. cyt., s. 25.

${ }^{78}$ Tenże, Mądre serce, w: tenże, Stowo o ślebodzie. Kazania spod Turbacza 1981-1997, Kraków 2003, s. 43. 
gę przekierować na słowo. Jest tu pewien paradoks i radykalizm zarazem, bo wydawać by się mogło, że w centrum spotkania będzie Twarz drugiego - Tischner w Filozofii dramatu bardzo inspirował się myślą E. Lévinasa. Pamiętać jednak należy, że do Twarzy Lévinasa również nie mamy dostępu wzrokowego, lecz etyczny, wyrażony za pomocą apelu, słowa: „ty mnie nie zabijesz”. Tischner mówi:

Być może ten przykład pomoże nam lepiej zrozumieć Pana Boga, który powiada do Mojżesza: słuchaj, nie ufaj tak bardzo wzrokowi. Owszem możesz patrzeć i coś widzieć, ale to, co jest widzialne, może sprawić ci zawód, okazać się ułudą, podlegać rozmaitym, również niewłaściwym interpretacjom. Mojżesz pragnął widzieć Stwórcę, bo mieszkając w Egipcie na dworze faraona, przyzwyczaił się do odbierania doznań wzrokowych. Tylko wówczas, kiedy mógł patrzeć, czuł się dowartościowany ${ }^{79}$.

Inaczej w Biblii: osią spotkania jest słowo, które prowadzi do wnętrza człowieka.

Bóg bierze udział w dramacie ludzkim, bo został wybrany, nie wchodzi doń, kierując się przemocą. Gdyby nie było ludzkiego wyboru, gdyby nie było otwarcia na Boga, Bóg by nie przyszedł: „Jeśli Boga nie wybierzemy, nie będzie Go wśród nas. Jest w tym odkrycie i dowartościowanie naszej wolności [...]. Bóg przychodzi poprzez ludzką wolność" ${ }^{80}$. Wolny Bóg rozszerza wolność człowieka, „wybierający Bóg uczy wybierania człowieka. Początkiem religii jest wybór, jest wolność. Nie ma tutaj żadnej przemocy" ". Następnym krokiem po dokonaniu wyboru jest wierność: „Wybór w języku biblijnym nazywany jest miłością. Kto miłuje, ten wybiera" ${ }^{\$ 2}$. Spotkanie z Bogiem odsłania nam zaś Jego dialogiczną naturę.

\section{Absolut dialogiczny}

Człowiek biorący udział w dramacie spotyka nie tylko drugiego człowieka, lecz także Boga. Samo pytanie o Boga jest dramatyczne. Czy Bóg jest? Jaki jest? Jaką ma twarz? Gdzie, i czy w ogóle, możemy Go spotkać? Skąd przychodzi? Punktem wyjścia do rozważań Tischnera o spotkaniu Boga i człowieka są słowa św. Augustyna: „Bóg jest bliżej człowieka, niż człowiek samego siebie”"83.

\footnotetext{
${ }^{79} \mathrm{WB}$, s. 61.

${ }^{80}$ Tenże, Zamieszkało miedzy nami, w: Wiara ze stuchania, dz. cyt., s. 78 .

${ }^{81} \mathrm{NA}-123$.

${ }^{82}$ J. Tischner, Zamieszkało miedzy nami, dz. cyt., s. 79.

${ }^{83}$ Św. Augustyn, Wyznania, przeł. Z. Kubiak, Kraków 2001, ks. III.6, s. 74.
} 
Wprowadzają nas one w samo serce dramatu religijnego: człowiek jest tak dziwnie zbudowaną istotą, że to, co dla człowieka najbliższe, jest też najdalsze i najtrudniejsze do osiągnięcia. Bóg jest blisko, ale droga człowieka do Niego wydłuża się. Człowiek może nawet nie spotkać Boga. Tischner posługuje się tutaj analizami św. Jana od Krzyża, który twierdzi, że aby dojść do Boga, należy usunąć nie Jego tajemnicę - Bóg zawsze pozostanie tajemnicą - ale zasłonę, która jest pomiędzy nami a Bogiem. „Zasłoną jesteśmy my sami” ${ }^{44}$ - zauważa Tischner. Ustanawia się zatem swoista spirala hermeneutyczna pomiędzy Bogiem a człowiekiem: ,„[...] prawdą jest, że aby odkryć Boga, trzeba popatrzeć na Boga przez człowieka, ale prawdą jest także coś odwrotnego, że aby odkryć człowieka, trzeba popatrzeć na niego przez Boga, którego się ma w sercu"85.

Bóg jest jednocześnie bliski człowiekowi, ale pozostaje dla niego tajemnicą. Tischner rozważa historię Mojżesza, który prosi Boga: „Spraw, abym ujrzał Twoją chwałę" (por. Wj 33,18). Mojżesz chce zobaczyć Boga. Ale w odpowiedzi słyszy: „Nie będziesz mógł oglądać mojego oblicza, gdyż żaden człowiek nie może oglądać mojego oblicza i pozostać przy życiu” (por. Wj 33,20). To tutaj ujawnia się, jaki Bóg jest. Bóg jest Tym, którego oblicza widzieć nie można. Bóg określa się tutaj negatywnie, apofatycznie, jest Kimś, kogo nie można oglądać. Ale jednocześnie daje On odpowiedź Mojżeszowi: „oto miejsce obok mnie, stań przy skale, gdy przechodzić będzie moja chwała, postawię cię w rozpadlinie skały i położę rękę moją na tobie, aż przyjdę, a gdy cofnę rękę ujrzysz mnie z tyłu, lecz oblicza mego tobie nie ukażę" (por. Wj 33,22). Ta wypowiedź Boga świadczy o tym, że jednak można Go zobaczyć, ale jedynie jako odchodzącego. W tym miejscu Tischner sięga po analizy Mistrza Eckharta, który używa staroniemieckiego słowa Abgeschiedenheit do opisu relacji między człowiekiem a Bogiem. Słowo to nie daje się dokładnie przełożyć na język polski. Oznacza ono tyle, co „do zobaczenia”, ale jednocześnie zawarta jest w nim obietnica powrotu, ponownego spotkania. I w taki właśnie sposób Bóg przychodzi do człowieka - wciąż słyszymy Jego głos, mówiący nam „do zobaczenia”, „do następnego spotkania”. Przechodzący obok człowieka Bóg nie mówi mu „odchodzę”, ale „do zobaczenia”. Te odejścia Boga są zawsze jakimś przygotowaniem powrotu. Bóg zostawia tęsknotę za sobą, ale nie taką, która rozpacza, lecz przepełnioną nadzieją powrotu. Tischner twierdzi, że „Bóg jest w nas jako wielka obietnica powrotu" ${ }^{\text {" }}$. Jest On tylko obietnicą, ale aż obietnicą powrotu. Istoty Boga nie można wyrazić dosłownie bez popadnięcia w paradoks: Bóg odszedł, ale jednocześnie nie odszedł. Odszedł przed spojrzeniem, rozumieniem,

\footnotetext{
${ }^{84}$ J. Tischner, Na drogach krzyżowych historii, dz. cyt., s. 8.

85 NA-230.

${ }^{86} \mathrm{~J}$. Tischner, Na drogach krzyżowych historii, dz. cyt., s. 10. Por. NA-143.
} 
które Go zniekształca, ale nie odszedł, bo stał się obietnicą powrotu. Bóg ,jest obecny obecnością obietnicy"

Powyższe stwierdzenia prowadzą nas do wniosku, że między Bogiem a człowiekiem nie jest możliwa żadna teraźniejszość. Za Bogiem można tęsknić, można Go oczekiwać, można pamiętać o tym, jak przeszedł, ale „teraźniejszość wymyka się człowiekowi i Bogu"88. Tym, co przywraca ową teraźniejszość, jest Słowo. W relacji człowieka i Boga kluczowym wydarzeniem jest wydarzenie Słowa. Bóg jest więc Absolutem dialogicznym.

Mówiąc o relacji człowieka do Boga, Tischner sięga też do analiz św. Augustyna i jego koncepcji tzw. wewnętrznego Nauczyciela, zawartej w dziele De Trinitate. Człowiek ma w sobie wewnętrznego nauczyciela, którym jest Chrystus, a który ,poucza człowieka nie poprzez dyktowanie słów, ale poprzez stwarzanie w nim wrażliwości naprawdę"89. Człowiek może rozróżniać prawdę od fałszu, gdyż w jego wnętrzu mieszka prawda.

Gdy połączymy obydwa wątki, z jednej strony Słowo Boga, z drugiej prawdę mieszkającą w człowieku, to zauważamy, że cała relacja człowieka z Bogiem ma charakter dialogu: „,w przestrzeni duchowej, w której pali się światło Prawdy, powstaje wielki dialog człowieka z Bogiem"90. Tischner ponownie wraca do św. Jana od Krzyża, który wyróżnia różne rodzaje słów, jakie przychodzą do człowieka od Boga, a wśród nich słowa o niezwykłej mocy działania. Nazywa je „słowami substancjalnymi”91. Charakteryzują się one tym, że sprawiają to, co oznaczają. Tischner tak je charakteryzuje:

Słowa substancjalne... Słowa, które padają w rozmowie człowieka z Bogiem. Słowa pochodzące od Wewnętrznego Nauczyciela, który mówi światłem i miłością prawdy. Kiedy padają słowa »nie lękaj się«, człowiek przestaje się lękać... Kiedy padają słowa »miłuj mnie«, człowiek zaczyna kochać... Słowa substancjalne, które nie opisują, ale tworząą

A zatem, pomiędzy Bogiem a człowiekiem jest Słowo. Tischner przywołuje słowa Ewangelii: „Nie samym chlebem żyje człowiek, ale i słowem, które pochodzi z ust Boga" (zob. Pwt 8,3 i Mt 4,4). To na tej podstawie może stwierdzić, że człowiek jest istotą tworzoną wewnętrznie przez Słowo: „Słowo określa prawdziwy rodowód człowieka"93.

${ }^{87}$ J. Tischner, Na drogach krzyżowych historii, dz. cyt., s. 10.

${ }^{88} \mathrm{NA}-143$.

${ }^{89}$ J. Tischner, Na drogach krzyżowych historii, dz. cyt., s. 10.

${ }^{90}$ Tamże, s. 11.

${ }^{91}$ Św. Jan od Krzyża, Droga na Górę Karmel, przeł. B. Smyrak, Kraków 2004, s. 324.

${ }^{92}$ J. Tischner, Na drogach krzyżowych historii, dz. cyt., s. 11.

${ }^{93}$ Tamże. 
Jednakże Słowo nie tylko stwarza. Zdaniem Tischnera, na gruncie Biblii Słowo jest zawsze wyrazem wierności: „,... [ ile razy Słowo znajdzie się między mną a tobą, tyle razy Słowo znaczy wierność. Wszystkie słowa skierowane przez Boga do człowieka są szczytem wierności. Opowiadają o jednym - o wierności"'94. Wierność to ważne określenie dramatu religijnego. Bóg jest wierny i dlatego mówi, a kiedy mówi - wypowiada wierność. Słowo Boga opowiada o wierności Boga.

Kolejną cechą charakterystyczną relacji człowieka z Bogiem jest tajemnica wybrania. Tischner przywołuje słowa św. Pawła: „Bóg z miłości przeznaczył nas dla siebie" (por. Ef 1,5). Świadczą one o wybraniu człowieka przez Boga. Człowiek z miłości Bożej został wybrany, przeznaczony do tego, żeby się spotkać z Bogiem ${ }^{95}$. W tajemnicy wybrania przejawia się wierność i miłość Boga: „Miłość jest wybraniem. Kto miłuje, ten wybiera, a kto wybiera, ten jest wierny swojemu wyborowi”96. To dlatego słowa św. Jana „Bóg jest miłością” (1 J 4,8) tak dobrze oddają istotę Boga. Słowo miłość jest bardzo ważne, bo ,poprzez to słowo widzimy tajemnicę Boga. I Bóg poprzez to słowo widzi także nas"97.

O wiele bardziej dramatyczną kwestią jest wierność człowieka. Człowiek również musi wybrać Boga. Całe życie człowiek dojrzewa do momentu, kiedy będzie mógł w swojej wolności wybrać Boga.

W istocie rzeczy - twierdzi Tischner - cały proces dojrzewania obecności Boga w sercu człowieka, czy może dojrzewania człowieka w sercu Boga, polega na tym, aby człowiek w pewnym momencie mógł do Boga powiedzieć: mój Bóg!98.

Tischner przywołuje biblijny obraz powołania Mojżesza, gdyż historia ta jego zdaniem - ukazuje wszystkie niemal elementy dramatu religijnego. Bóg kieruje do Mojżesza słowo. Jeszcze raz widać, jak słowo staje się pomostem pomiędzy Bogiem a człowiekiem. Bóg wybiera Mojżesza i na swój wybór oczekuje odpowiedzi. Pojawia się niezwykłe napięcie, co zrobi Mojżesz? Odpowiedź nie jest wcale oczywista. W historii zdarzało się wiele powołań, były sytuacje, kiedy Bóg wołał kogoś po imieniu, jak np. Adama w Raju, a ten ktoś uciekał lub chował się. Czy Mojżesz odpowie Bogu? To jest napięcie dramatu religijnego. Zwróćmy uwagę, że wolny Bóg zwraca się do wolnego Mojżesza, oczekując jego wolnej decyzji. W dramacie religijnym „wolność budzi wolność" ${ }^{99}$, nie ma

\footnotetext{
${ }^{94}$ NA-143.

95 Por. J. Tischner, Pamięć serca, w: Wiara ze stuchania, dz. cyt., s. 57.

96 NA-123.

97 J. Tischner, Wybór miłości, w: Wiara ze stuchania, dz. cyt., s. 95.

${ }_{98}$ Tenże, Ja i mój Bóg, w: tenże, Miłość niemiłowana, dz. cyt., s. 62.

99 NA-123.
} 
w nim żadnej przemocy. Tym się on różni od pogaństwa. Tam również bóstwo wchodziło w relację z człowiekiem, ale na zasadzie fatum: „Fatum działało bez słów, działało podstępem, często przemocą. Fatum zwodziło i uwodziło, fatum nie dało się rozumieć, oślepiało człowieka, ogłuszało go, niszczyło"100. Tutaj jest zupełnie inaczej. Bóg nie działa podstępnie, nie uwodzi człowieka, nie okłamuje go, ale działa za pomocą Słowa, które jest jasne, otwarte, daje się zrozumieć. „Dzięki Słowu staje się możliwe porozumienie między Bogiem a człowiekiem”101. Dramat religijny jest spotkaniem dwóch wolności.

W rozmowie miedzy Mojżeszem a Bogiem daje się wyczuć pewne charakterystyczne napięcie. Mojżesz nie pada na twarz przed Bogiem, ale stawia mu pytanie. Jest to postawa wiele mówiąca, gdyż „stawiać pytanie to wymagać, żądać, grozić nawet - nie będzie odpowiedzi, nie będzie także posłuszeństwa"102. Widać tu szczególny dialog pomiędzy człowiekiem i Bogiem, który przybiera kształt sporu. To jest w pewnym sensie konsekwencja spotkania dwóch wolności i spór staje się istotnym elementem dramatu religijnego: „W tym początku religii między Bogiem a człowiekiem, w tym początku niezwykłej więzi, jest jakiś moment sporu. Człowiek nie tylko prosi Boga, ale człowiek także spiera się z Bogiem"103. Dopiero w sporze z Bogiem człowiek staje się kimś odpowiedzialnym za świat, za siebie, za innych. Mojżesz daje pozytywną odpowiedź: „Oto jestem" (por. Wj 3,4). Dotykamy tutaj tego, co jest największą tajemnicą spotkania człowieka z Bogiem: „Człowiek poczuł się w świecie, jak u siebie w domu. Może teraz podjąć czyn (...)"104.

Dramat religijny odsłania nam niespodziewane oblicze Boga. Jak powie Tischner: „Wybierający Bóg uczy wybierania człowieka”"105. Co się dzieje, kiedy Bóg zostaje wybrany przez człowieka? Wtedy „Słowo staje się ciałem i mieszka między nami”(por. J 1,14). Ewangeliczna formuła „między nami” jest bardzo ważna dla zrozumienia dramatu człowieka. To ona właśnie odsłania szczególne oblicze Boga i pokazuje prawdziwą istotę religii. Bóg, który mieszka „między nami”, jest kimś innym niż światło, niż potęga stwórcza. Jest Kimś, kto się pojawia w przestrzeni międzyludzkiej. Ale żeby tak było musi być wybrany: „Istnienie Boga między nami jest złożone w ręce naszej zdolności wyboru. Jeżeli Go nie wybierzemy, nie będzie Go między nami [...]"106. W dramacie religijnym zatem Bóg pojawia się jakby na nowym poziomie - z poziomu potęgi stwórczej wchodzi na poziom przestrzeni międzyludzkiej: „Bóg pojawia się w tej przestrzeni,
100 Tamże.
101 Tamże.
102 Tamże.
103 Tamże.
${ }^{104} \mathrm{~J}$. Tischner, Odpuszczenie grzechów, w: tenże, Miłość niemiłowana, s. 75.
105 NA-123.
106 NA-143. 
która istnieje między człowiekiem a człowiekiem, między mną a tobą, miedzy nami. Nie jest w tobie, nie jest we mnie. Jest między nami”"107. A zatem i szukać Go powinniśmy między nami, w tym, co łączy człowieka z człowiekiem. W ten sposób dochodzimy do prawdziwego znaczenia słowa religia: „Łacińskie słowo religio znaczy więź [...]. Ewangelia buduje więź pomiędzy człowiekiem a Bogiem, pomiędzy człowiekiem a drugim człowiekiem"108. A zatem religia to nie jest coś, co wydarza się tylko między Bogiem a człowiekiem. Można mówić o trzech podmiotach dramatu religijnego: ja, drugi człowiek i Bóg. Religia twierdzi Tischner - ,jest dialogiem, rozmową, między Bogiem a człowiekiem, człowiekiem i drugim człowiekiem"109. W ten sposób człowiek jest wyrwany z groźnej herezji, którą można określić jako solipsyzm religijny, a która wyraża się w postawie ,ja i mój Bóg”. Wtedy cała religijność zamyka się w stosunku pomiędzy człowiekiem a Bogiem. Dla tej religijności nie ma świata zewnętrznego, nie ma kategorii bliźniego, wszystko inne jest nieważne. Tymczasem wiara chrześcijańska polega na czym innym: „Ponieważ Bóg umiłował ciebie, więc ty masz miłować bliźnich"

Gdybyśmy chcieli nadać tak opisanej religii jako więzi jakąś treść, to należałoby powiedzieć, że jest ona więzią zbawienia. Tym, co ustanawia ową więź, jest ofiara Chrystusa na krzyżu. Dotykamy tu jednocześnie tajemnicy cierpienia, która nie została - zdaniem Tischnera - jako dotąd rozwiązana przez jakąkolwiek filozofię. Czyni to dopiero wiara chrześcijańska, ,ale nie w ten sposób, że proponuje nam jakąś koncepcję cierpienia [...], ale w tym sensie, że czyni z cierpienia ofiarę, a z ofiary więź"111. Żeby to dobrze wytłumaczyć Tischner wprowadza rozróżnienie pomiędzy męczeństwem a ofiarą. Jego zdaniem, nie każde męczeństwo jest ofiarą. Ofiara tym się różni od męczeństwa, że coś usprawiedliwia, a usprawiedliwiając ocala: „Męczeństwo po prostu oznacza, że człowiek zostaje umęczony. $Z$ tego męczeństwa nie musi płynąć ofiara. Ofiara dorzuca do męczeństwa ten szczególny moment - jest ofiarą za kogoś. A ponieważ jest ofiarą za kogoś, coś w kimś usprawiedliwia"112. Usprawiedliwić, to znaczy sprawić, żeby coś stało się wartością. Bóg usprawiedliwiając człowieka, pokazuje, że ten człowiek jest wartością. W jaki sposób można to uczynić? Zdaniem Tischnera nie ma takich słów, takiej siły perswazyjnej, która mogłaby wykazać, że człowiek jest wartością: „to wykazuje się inaczej - przez poświęcenie. Jeśli poświęcę się za ciebie, jesteś wartością, a jeśli nie, nie jesteś" ${ }^{113}$. Mamy tutaj cały dramat religijny

\footnotetext{
${ }^{107}$ J. Tischner, Zamieszkało między nami, dz. cyt., s. 77.

${ }^{108}$ NA-210.

109 NA-223.

${ }^{110} \mathrm{~J}$. Tischner, Wimię miłości, w: Wiara ze stuchania, dz. cyt., s. 141.

${ }^{111}$ J. Tischner, Rekolekcje wielkopostne, Oświęcim 2007, s. 35.

112 Tamże, s. 39.

113 Tamże, s. 41.
} 
jakby w pigułce. Tischner wiele razy powtarza, inspirując się koncepcją F. Rosenzweiga, że „dramat religijny ma trzy węzłowe wydarzenia: stworzenie, objawienie, czyli wybranie i zbawienie, czyli odkupienie"114. To one określają sens owego dramatu, w którym każdy człowiek ma swój udział. Bóg Stwórca stworzył na początku świat. Ale samo powołanie świata do istnienia nie oznacza, że ma on jakąś wartość. Dopiero wybranie i śmierć Syna Bożego było prawdziwym stworzeniem wartości: „Syn człowieczy, który poświęcił się za człowieka, stworzył człowieka jako wartość. Absolutne poświęcenie ustanowiło absolutną wartość człowieka" ${ }^{115}$. Stąd wypływa potrzeba wdzięczności ze strony człowieka.

Więź człowieka z Bogiem i z drugim człowiekiem jest również więzią wdzięczności. Oddaje ją słowo łaska, gratia, czyli wdzięk, „wzajemna wdzięczność Boga i ludzi" "116. Wierność łączy się z wdzięcznością. To dlatego Tischner powie, że „chrześcijaństwo niesie w sobie wielką metafizykę wdzięczności”117.

Warto w tym miejscu zauważyć, że łaska jest czymś, przy pomocy czego chrześcijaństwo pokonywało pogańskie fatum. Czym jest fatum? Była już o tym częściowo mowa powyżej. Teraz chcemy dopowiedzieć, że wiara w fatum to podstawowe zło, jakie zagraża relacji człowieka z Bogiem. Jest to główna cecha myślenia pogańskiego. Pogaństwo znało ideę męczeństwa, ale nie znało idei ofiary. W kulturze pogańskiej występuje wielu bohaterów, którzy zostali męczennikami: Prometeusz, Edyp, Antygona. To w ich losie ukazywała się uniwersalna prawda o dramacie człowieka. Fatum to zły los, przeznaczenie człowieka, przed którym nie można uciec. Bohater grecki przegrywał w starciu z fatum, a jego los stawał się natchnieniem dla poety czy pieśniarza. To właśnie twórcy dążyli do tego, by tragedię człowieka przemienić w dzieło sztuki. Sztuka grecka, zamiast rozpaczać nad losem bohatera, skłania do podziwiania tragicznej historii ludzi. Tischner nazywa ten zabieg „estetycznym przezwyciężeniem tragedii”"118. Ale zauważa, że nie jest ono całkowite i ostateczne. Dlaczego? „(...) bo estetyka nie stwarza więzi" 119 . Wszyscy bohaterowie są absolutnie sami, nikt nie jest im za nic wdzięczny. Jest fatum, ale nie ma wiernej wdzięczności, bo też nie ma i usprawiedliwienia.

Chrześcijaństwo tym się różni od pogaństwa, że nie jest wiarą w fatum, ale więzią łaski. Chrystus nie jest sam, od samego początku wzbudza wyznawców, czyli tych, którzy są mu wdzięczni. Miejsce fatum zajmuje łaska. To ona wiąże ludzi między sobą. Przynosi wyzwolenie i prowokuje do wdzięczności. Tischner,

\footnotetext{
114 Tamże, s. 28.

115 Tamże, s. 42.

116 Tamże.

117 Tamże, s. 43.

118 Tamże, s. 44.

119 Tamże.
} 
komentując św. Pawła, powie, że „łaska wiąże się z trzema doświadczeniami: pierwsze to doświadczenie objawienia, drugie to doświadczenie jakiegoś usprawiedliwienia, a trzecie to doświadczenie wyzwolenia" ${ }^{120}$. W dramacie religijnym człowiek zyskuje wolność.

Tischner trafnie wyraził swój pogląd: „Biblia to inne problemy i inny sposób przedstawiania" ${ }^{\prime 21}$. Przedstawiliśmy biblijne elementy Tischnerowskiej filozofii dramatu, a także jego oryginalny sposób podejścia do Pisma. Możemy powiedzieć, czym Biblia dla Tischnera jest, a czym nie jest. Nie jest jedynie zbiorem metafor, toposów, związków frazeologicznych, którymi można by swoje wywody inkrustować. Biblia wobec filozofii dramatu Tischnera jest źródłem w tym sensie, że ustanawia zupełnie nowy paradygmat myślenia. Odsłania ona prawdę o Bogu i o człowieku. Tischner, sięgając po myślenie biblijne, rozwinął jedną $\mathrm{z}$ bardziej oryginalnych antropologii XX wieku.

\section{Bibliografia}

Bobko A., Doświadczenie zła jako źródło myślenia religijnego, w: Między potępieniem a zbawieniem. Myślenie religijne ks. Józefa Tischnera, red. J. Jagiełło, W. Zuziak, Kraków 2004.

Bobko A., Myślenie wobec zła. Polityczny i religijny wymiar myślenia w filozofii Kanta i Tischnera, Kraków-Rzeszów 2007.

Buttiglione R., Osobowy charakter prawdy, przeł. M. Przychodzeń, w: O autorytecie. W poszukiwaniu punktu odniesienia, red. J. Jagiełł, Kraków 2008.

Dymarski Z., Dwugłos o złu. Ze studiów nad myśla Józefa Tischnera i Leszka Kołakowskiego, Gdańsk 2009.

Gadacz T., Historia filozofii XX wieku, tom 2, Kraków 2009.

Gadacz T., Problem zła w filozofii Józefa Tischnera, „Horyzonty Wychowania” 2005, nr 4.

Karpiński P., Zrozumieć człowieka. Antropologia kazań Ks. Józefa Tischnera, Sandomierz 2012.

Lévinas E., La souffrance inutile, „Giornale di Metafisica” 1982, nr 1.

Św. Augustyn, Wyznania, przeł. Z. Kubiak, Kraków 2001.

Św. Jan od Krzyża, Droga na Górę Karmel, przeł. B. Smyrak, Kraków 2004.

Tischner J., Filozofia dramatu, Kraków 2006.

${ }^{120}$ Tenże, Wiara szuka zrozumienia, w: Miłość niemiłowana, dz. cyt., s. 93.

121 WB, s. 7. 
Tischner J., Hermeneutyka. Zagadnienie języka i interpretacji dzieł językowych, w: Filozofia współczesna, red. J. Tischner, Kraków 1989.

Tischner J., Ksiażeczka pielgrzyma, Kalwaria Zebrzydowska 2002.

Tischner J., Miłość niemiłowana, Kraków 1993.

Tischner J., Myślenie wedlug wartości, Kraków 2005.

Tischner J., Na drogach krzyżowych historii. Rekolekcje 1982, Kraków 1982.

Tischner J., Rekolekcje wielkopostne, Oświęcim 2007.

Tischner J., Stowo o ślebodzie. Kazania spod Turbacza 1981-1997, Kraków 2003.

Tischner J., Spór o istnienie człowieka, Kraków 2001.

Tischner J., Wiara ze stuchania. Kazania starosadeckie 1980-1992, oprac. W. Bonowicz, Kraków 2009.

Tischner J., Zarys filozofii człowieka dla duszpasterzy i artystów, w: Myślenie w żywiole piękna, Kraków 2004.

Wokół Biblii. Z ks. Józefem Tischnerem rozmawia Ewelina Puczek, Kraków 2005.

Wokół myślenia religijnego, „Znak”, 2004, nr 5.

\section{Streszczenie}

\section{Biblia w filozofii dramatu ks. Józefa Tischnera}

Ważną częścią Tischnera refleksji o człowieku jest tzw. myślenie religijne, które traktuje religię i pisma religijne jako ważne źródło poznania antropologicznego. Tym, co kazało Tischnerowi włączyć religię do swojej filozofii jest bezradność czysto racjonalnego dyskursu w wyjaśnianiu trudnych obszarów dotyczących człowieka, a zwłaszcza problemu zła. Biblia nie jest więc dla Tischnera zbiorem egzemplów i toposów, które mogłyby ilustrować rozwijaną przez niego myśl, ale źródłem, z którego ta myśl paradygmatycznie wyrasta. Przedmiotem artykułu jest ukazanie Biblii jako źródła Tischnerowskiej filozofii człowieka.

Myślenie biblijne różni się radykalnie od myśli greckiej. Jest ono o wiele bardziej dialogiczne, badające obszar wolności człowieka, a sama Biblia jest dla Tischnera wielką wizją moralną. Jej cechą charakterystyczną jest posługiwanie się językiem symbolicznym, co domaga się stosowania określonych zasad hermeneutycznych. Artykuł omawia następnie trzy obszary filozofii Tischnera, w których Biblia ujawnia swój źródłowy charakter: problem zła, dramat człowieka i dialogiczność Boga. 


\section{Summary \\ The Bible in the Józef Tischner's philosophy of drama}

Religious thinking, treating religion and religious writings as an important source of anthropological knowledge, is an important part of the Tischner's reflection about human being. The reason of including religion into his philosophy was the helplessness of the pure rational discourse in the face of explaining the most difficult areas concerning man, especially the problem of evil. The Bible for Tischner is not the collection of the examples and toposes which could illustrate the thought that he developed, but source this philosophy paradigmatically raise from. The subject of this paper is to show the Bible as a source of the Tischner's philosophy of man.

Biblical thinking is radically different from the greek one. It is much more dialogical, exploring the area of freedom and the Bible is for Tischner the great moral vision. Its characteristic feature is using the symbolic language, so that it demands the application of specific hermeneutical rules. Subsequently the article discusses three areas of the Tischner's philosophy in which the Bible reveals its source character: the problem of evil, the drama of man and the dialogical Absolute. 